\title{
KEY SUCCESS FACTORS FOR ENTREPRENEURS IN THE HEALTHCARE BUSINESS OF THAILAND
}

\author{
Tanapol Kortana
}

\author{
Suan Sunandha Rajabhat University, Bangkok, Thailand
}

Healthcare business in Thailand has been hugely popular among foreigners and retired persons especially. The research presented here focuses on the question "How to become and remain a healthcare entrepreneur?". The objectives have been formulated in the following way: 1) to study the success factors of the healthcare business in Thailand, and 2) to analyze the key success factors of entrepreneurs in this field. The population of the study is 6,717 people. The sample group has been 315 people, the stratified random sampling has been applied. The key success factors include education, investment plan, place/location, nurses, supporting staff and strategy. Education has got the highest score - 0.75. Most entrepreneurs have graduated with a bachelor degree or higher. The second comes strategy with the score of 0.636. As this business is quite famous, the competitors apply various strategies to get more customers, both local and international. Information technology and $4 P s$ are used for campaigns, for example. The lowest score in terms of business success impact got the investment plan with 0.528.

Keywords: success factors, entrepreneurs, healthcare business, Thailand.

\section{Introduction}

Nowadays the population structure of the world is changing, and the key trend is aging society. The United Nations states that any nation, which has a senior population share (those who are more than 60 years old) over $20 \%$, can be considered an aging society. Since the share of young population is decreasing while the share of senior population is increasing in so many countries at the same time, there will be serious changes in consumer demand in most of these aging society. Therefore, healthcare business for senior citizens is an increasingly important segment of healthcare business in general.

According to the senior population survey carried out back in 2015 (United Nations, 2016), there is high demand for help for senior citizens who are over 80 years old. The United Nation has classified the aging society into three categories. First is aging society. This is when more than 10 percent of population are 60 years old and above, or there is more than $7 \%$ of population being 65 years old and above.

The second category is aged society. This is when there is more than $20 \%$ of population being in the age of 60 years old or above, or there is more than 14 percent of population being 65 years old or above. The third and last category is super-aged society. This is when there is more than $20 \%$ of population being 65 years old and above (Foundation

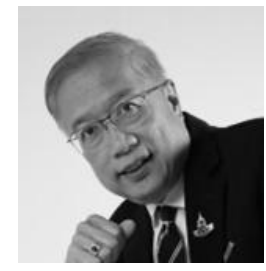

\section{Tanapol Kortana}

Dr., Ph.D. in Innovative Management

College of Innovation and Management, Suan Sunandha Rajabhat University, interests - Innovation, Management, Change Management

E-mail: tanapol.ko@ssru.ac.th 


\section{THE KEY SUCCESS FACTORS FOR ENTREPRENEURS}

and Research Institution for Senior Citizens of Thailand, 2016). Thus, it is important to satisfy the increasing demand for healthcare services designed specifically for senior citizens and ageing societies.

Thai government is aware of this problem (and opportunity at the same time) and tries to promote the local senior healthcare business in many of rural areas and suburban areas of Thailand (SCB Economic Intelligence Center, 2016). However, it is not easy for new entrepreneurs to be successful in the world of severe competition, mostly due to rapid changes in technology as well as same rapid changes in consumer behavior. However, good candidates to become entrepreneurs in the subsector of senior healthcare are registered nurses, for example, since they have all basic skills and sufficient knowledge to provide daily healthcare for senior citizens (Wongleedee, 2013). Therefore, this research has the aim to investigate in detail the key success factors in healthcare for senior citizens.

\section{Literature review}

\section{Marketing Mix}

Marketing mix refers to the set of actions, or tactics, that a company uses to promote its brand or product at a market. The 4Ps make up a typical marketing mix - Price, Product, Promotion and Place. However, nowadays, marketing mix increasingly includes several other Ps like Packaging, Positioning, People and even Politics as also vital elements.

Price: refers to the value that is put into a product. It depends on production costs, the segment targeted, the ability of the market to pay, the balance of supply and demand and a variety of other direct and indirect factors. There can be several types of pricing strategies, each tied closely with a specific business plan. Pricing can also be used a demarcation, to differentiate and enhance the image of a product.

Product: refers to the item actually being sold. The product must have at least the minimum level of performance; otherwise, even the best work on the other elements of the marketing mix won't do any good.

Place: refers to the point of sale. In every industry, catching the eye of a consumer and making it easy for him/her to buy is the main aim of a good distribution and/or placement strategy. Retailers always pay a premium for the right location.

Promotion: refers to all activities undertaken to make a product or a service known to the market and all consumer at it. This may include advertising, word of mouth, media coverage, incentives, commissions, trade awards for best quality or design etc. Here also belong various consumer schemes, direct marketing, contests and prizes.

\section{Human Resource Management}

Human Resource Management (HRM) has gained rapid and widespread acceptance as a new term for managing employment. It remains, however, an ambiguous concept. People question whether it is any different from traditional personal management, nor is it altogether clear what it consists of in real business practice.

\section{Matching employment practices to business strategy}

The key elements of a human resource (HR) system are: selection, appraisal development (including training), and reward. All of these stages have some sort of potential 
to channel behavior towards specific performance goals, if properly aligned with one another. Our vision of the human resource cycle is offered in Fig. 1.

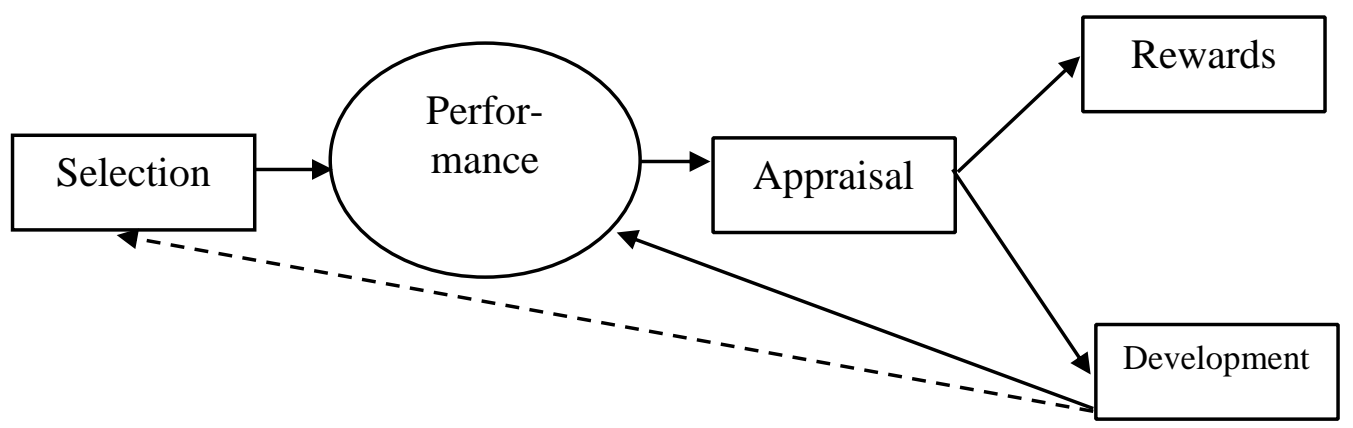

Figure 1. Human Resource Cycle

(made by the author)

\section{Methodology}

\section{Research methodology}

\section{Population and sampling}

Population: Population in this research consists of 6,717 people in total.

Sample: For sampling, the researcher has chosen the criteria for the sample size offered by Comrey and Lee (1992). These authors proposed the sample size for components analysis for 300 people as a good one; therefore, the researcher specifies to set the minimum sample size as 315 people. Stratified random sampling was applied to collect data.

\section{Tool used in this research}

The key tool used in this research is the questionnaire with the scale of 5 points such as very high, high, middle, low, and very low. We asked 3 professionals in the related field to assess the validity, and they found the Index of Item-Objective Congruence to be within the range of 0.60-1.00. After that, the final version of questionnaires was created and passed for content validity and professional test to inspect the reliability. The Cronbach alpha coefficient was found to be equal to 0.98 .

\section{Data Analysis}

Confirmatory components analysis was applied afterwards.

Data suitability was checked with the components analysis using the Kaiser-MeyerOlkin Measure of Sampling Adequacy (KMO) as it is described, for example, in (Angsuchock, Wijitwanna and Pinyonuwat, 2009)

The value of KMO is more than 0.80. This proves very high suitability in the component analysis.

The relation of variables was analyzed statistically using the Bartlett's test of sphericity with the following hypotheses:

H0: Variables have no relation.

$\mathrm{H} 1$ :Variables have relation. 


\section{THE KEY SUCCESS FACTORS FOR ENTREPRENEURS}

Statistically significant result was found so that to accept H1, which means the variables have relation, thus, we've proceeded with the component analysis (Yuth Kaiyawan, 2013: 74).

Structural integrity analysis of Key Success Factors and 4P's was supported by the confirmatory factor analysis: CFA - using AMOS 21 program and considering the structural accuracy of components (Hair et al., 2010; Schumacker \& Lomax, 2010; Jöreskog \& Sörbom, 2012) using the Goodness of Fit Statistics: $\mid 2$ has no statistical significance $p$ > 0.05, RMSEA <0.05, NFI $>0.90, \mathrm{CFI}>0.90, \mathrm{RMR}<0.05$, GFI $>0.90$ and AGFI $>0.90$.

\section{Results}

\section{Data analysis results}

Table 1. Correlation coefficients between the observed variables of Key Success Factors $(n=315)$

(calculated by the author)

\begin{tabular}{|l|c|c|c|c|c|c|}
\hline Talent Variable & Education & $\begin{array}{c}\text { Investment } \\
\text { Plan }\end{array}$ & Place & Nurses & $\begin{array}{c}\text { Supporting } \\
\text { Staff }\end{array}$ & Strategy \\
\hline Education & 1.000 & & & & & \\
\hline Investment Plan & $.406^{* *}$ & 1.000 & & & & \\
\hline Place & $.384^{* *}$ & $.266^{* *}$ & 1.000 & & & \\
\hline Nurses & $.257^{* *}$ & $.294^{* *}$ & $.350^{* *}$ & 1.000 & & \\
\hline Supporting Staff & $.463^{* *}$ & $.490^{* *}$ & $.398^{* *}$ & $.293^{* *}$ & 1.000 & \\
\hline Strategy & $.490^{* *}$ & $.336^{* *}$ & $.345^{* *}$ & $.351^{* *}$ & $.362^{* *}$ & 1.000 \\
\hline \multicolumn{7}{|c|}{ KMO : Measure of Sampling Adequacy $=.811$} \\
\hline
\end{tabular}

Table 1 shows that the correlation coefficients within the observed variance of all 6 variables have the relationship in all 15 pairs; they have the values more than zero at the statistical significance level of 0.01 . Every pair means the correlation of the variables have a positive relationship or relationship at the same direction, they have the values from 0.257 to 0.490 . The correlation coefficients of the observed variables demonstrate the highest value at 0.490 for the relationship between Education and Strategy and also for the relationship between investment plan and supporting staff; then, with the value of 0.463 , goes the relationship between Education and Supporting Staff; and the lowest value of 0.257 has been found for the relation between Education and Nurses.

Beside this, the researcher has done the Bartlett's Test of Sphericity to inspect whether the relationship matrix of the observed variables is matrix identity or not. The result is that Chi-Square $=430.164, \mathrm{df}=15, \mathrm{p}=0.000$, different from the zero statistical significance at 0.01 , including the relationship to the index analysis result of Kaiser-Meyer-Olkin (KMO), the value of 0.811 being closer to 1 . Therefore, the correlation matrix of the observed variables is not matrix identity. Confirmatory analysis results are presented in Table 2. 
Table 2. Confirmatory components analysis results for the Key Success Factors $(n=300)$ (calculated by the author)

\begin{tabular}{|l|l|c|c|c|c|c|}
\hline \multirow{2}{*}{ Components } & \multirow{2}{*}{$\begin{array}{l}\text { Observed } \\
\end{array}$} & Variables & \multicolumn{5}{|c|}{ Component weight value } \\
\cline { 3 - 7 } & $\mathrm{b}_{\mathrm{sc}}$ & $\mathrm{S} . \mathrm{E}$. & $\mathrm{t}$ & $\mathrm{p}$ & $\mathrm{R}^{2}$ \\
\hline Key Success & Education & .750 & $\langle--\rangle$ & $\langle-->$ & $<-->$ & .562 \\
\hline & Investment Plan & .528 & .094 & 7.678 & .000 & .279 \\
\hline & Place & .559 & .094 & 8.207 & .000 & .312 \\
\hline & Nurses & .554 & .112 & 7.356 & .000 & .307 \\
\hline & Supporting Staff & .602 & .086 & 8.579 & .000 & .363 \\
\hline & Strategy & .636 & .097 & 9.036 & .000 & .405 \\
\hline
\end{tabular}

Legend: $b_{s c}$ means the standard component weight value, $R^{2}$ means the forecast coefficient, mark <- -> means parameter enforcement does not report S.E.t value and $\mathrm{p}$.

Tab. 2 shows that the structure validity inspection result for the Key Success Factors along with the confirmatory components analysis found that the model had a harmony correlation with the following empirical information to be considered: Chi Square value $=$ $8.347, \mathrm{df}=7, \mathrm{p}=0.303, \mid 2$ is not different from zero at the level of statistical significance being 0.05 and $\mid 2 / \mathrm{df}=1.192$ which had the value of less than 2 and the index value RMSEA $=0.025, \mathrm{RMR}=0.011$, it had the value very close to 0 , the index value $\mathrm{GFI}=0.992, \mathrm{AGFI}=$ $0.954, \mathrm{CFI}=0.997$ all being very close to 1 , thus showing that the measure model of Key Success Factors had structure validity for components' weights. All the variables have positive values, different from zero at the level of statistical significance being 0.05 . The largest weight has got the variable Education - 0.750, while the smallest component weight got the variable of Investment Plan - 0.528. More details are demonstrated in Fig. 2.

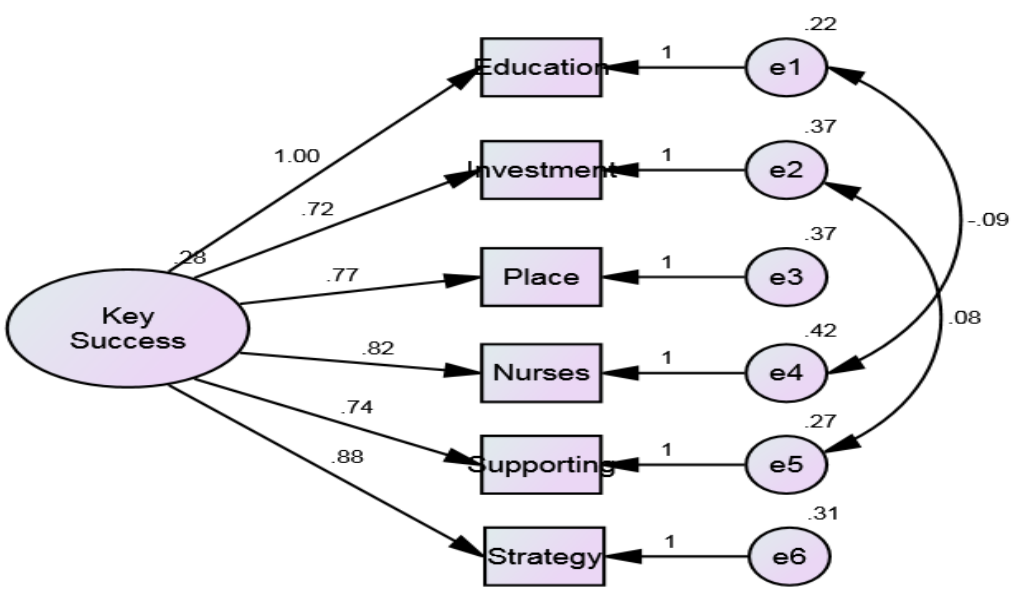

CHI-SQUARE=8.347, CHI-SQUARE/DF=1.192, DF=7, P-VALUE $=.303$, RMR $=.011$, RMSEA $=.025$, $\mathrm{CFI}=.997, \mathrm{GFI}=.992, \mathrm{AGFI}=.975$

Figure 2. Key Success Factors’ Analysis

(designed by the author) 


\section{THE KEY SUCCESS FACTORS FOR ENTREPRENEURS}

\section{Acknowledgement}

The author would like to thank the Research and Development Institute, Suan Sunandha Rajabhat University, Bangkok, Thailand for financial support.

\section{References:}

Angsuchock, S., Wijitwanna, S. \& Pinyonuwat, R. (2009). Lisrel Program for Social Science Analysis. Bangkok, Charendee Printing.

Chen, J. S. (1998). The tourists' cognitive decision making model. The Tourist Review, 53.

Comrey, A. \& Lee, H. (1992). A first course in factor analysis. Hillsdale: Lawrence Erlbaum Associates.

Foundation and Research Institution for Senior Citizens of Thailand (2016). Report of situation of senior citizens in Thailand.

Handbook of Senior Nursing (2016). Prepare for senior business and aging society of Thailand. Bangkok, Thailand.

Hair, J.F., Black, W.C., Babin, B.J. \& Anderson, R.E. (2010). Multivariate Data Analysis. New Jersey: Pearson Education, inc.

Joreskog, K.G. \& Sorbom, D. (1989). LISREL 7: User's Reference Guide. Mooresville: Scientific Software.

Kotler, P. (2000). Marketing management. Prentice Hall International.

Rauyruen, P., Miller, K. E., \& Barret, N. J. (2007). Relation quality as a predictors of B2B loyalty. Journal of Business Research, 21-32.

SCB Economic Intelligence Center (2016). In-sight senior business booming in Thailand. Bangkok, Thailand.

Schumacker, R. E. \& Lomax, R. G. (2010). A beginner's guide to structural equation modeling. New Jersey: Lawrence Erlbaum Associates.

Tylor T. (1998). Better loyalty measurement leads to business solution. Market News, 31(22). pp. 171-177.

United Nations (2016). Department of economic and social affairs, population division, world population aging. United Nation Press.

Wongleedee, K. (2013). Satisfaction: Global senior tourists in Thailand. Conference Proceedings. International College, Suan Sunandha Rajabhat University.

Yoon, Y., \& Uysal, M. (2005). An examination of the effects on motivation and satisfaction on destination loyalty: A structural model. Tourism Management, 26(1), pp. 45-56.

Paper submitted

Paper accepted for publishing

Paper published online
14 April 2018

16 June 2018

31 July 2018 